\title{
当科における喉頭・気管・食道の合併切除を要した 甲状腺癌症例の検討
}

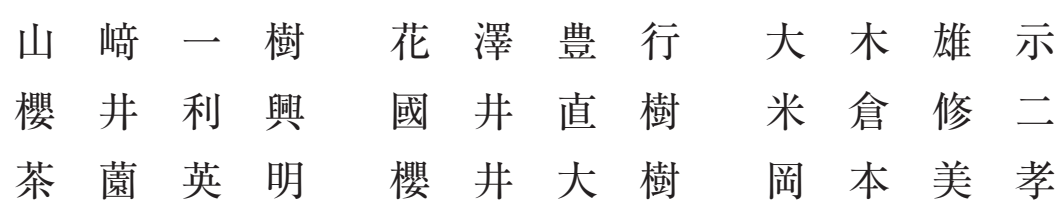

要旨： 2008 年から 2016 年の間に当科で治療した甲状腺癌症例は 219 症例であった。喉頭，気管および食道の いずれかに浸潤し，合併切除を要した 24 症例のうち，再発症例，未分化癌症例，CASTLE症例を除いた 13 症例の検討を行った。浸潤部位の内訳は気管のみの浸潤が 4 例, 気管と輪状軟骨浸潤が 5 例, 気管と食道浸潤 が 1 例，気管，輪状軟骨と甲状軟骨浸潤が 3 例であった。

3 年粗生存率は $72.5 \%$ であった。再発症例は 5 例存在し, 再発形式はそれぞれ, 遠隔転移が 3 例, 健側リン パ節再発が 1 例, 局所再発が 1 例であった。

局所再発症例は切除マージン不足による再発が考えられた。腫瘍切除に際して, 断端陰性と顕微鏡的断端陽 性症例との間の局所再発に差はないとする報告もあるが，Ex2 と判断された場合には，局所再発を回避するため に周囲臓器の切除の際には十分な切除マージンが必要であると考える。切除範囲は, 術中迅速病理診断や術後 の QOL，年齢や併存疾患，術前の鱟下機能，家族背景掞よび予後も考慮して慎重に決定されなければならない。 キーワード : 甲状腺癌, 喉頭浸潤，気管浸潤，食道浸潤

Summary Results of cases with combined resection of larynx, trachea and/or esophagus for thyroid carcinoma:

Kazuki Yamasaki, Toyoyuki Hanazawa, Yuji Ohki, Toshioki Sakurai, Naoki Kunii, Syuji Yonekura, Hideaki Chazono, Daiju Sakurai and Yoshitaka Okamoto. Department of Otorhinolaryngology/Head and Neck Surgery, Graduate School of Medicine, Chiba University

A total of 219 patients underwent surgical treatment for thyroid carcinoma in our department between 2008 and 2016; 24 of these patients underwent combined resection of the larynx, trachea, and/or esophagus due to tumor invasion. Thirteen of the 24 cases were examined, excluding undifferentiated carcinoma, CASTLE, and recurrent carcinoma. The tumors invaded the trachea, the trachea and cricoid cartilage, the trachea and esophagus, and the trachea, cricoid and thyroid cartilage in 4, 5, 1, and 3 patients, respectively.

The 3-year survival rate was $72.5 \%$. Five patients relapsed (3 with distant metastases, 1 with a relapse of the contralateral cervical lymph nodes, and 1 with local recurrence).

The local recurrence was thought to be due to positive surgical margins. Some reports have found no difference in local recurrence between resections with negative surgical margins and those with microscopically positive margins. However, we suggest that sufficient surgical margins are essential for preventing local recurrence after tumor resection for Ex2 cases. Surgical margins must be carefully delineated for intraoperative pathological diagnosis and should take into consideration future QOL, age, past medical and surgical history, swallowing function, and prognosis.

Key words: thyroid carcinoma, laryngeal invasion, tracheal invasion, esophageal invasion 


\section{はじめに}

甲状腺癌の予後は比較的良好であり, 分化癌の 10 年生存率は $90 \%$ 前後とされているが, 遠隔転移, 分化度, 腫瘍や転移リンパ節の大きさなどの予後増 悪因子も報告されている。特に周囲臓器への浸潤が 認められた症例の予後は悪く ${ }^{1)}$, その治療方針も確 立されていないのが現状である。今回, 当科で手術 を行った甲状腺癌症例のうち, 周囲臓器, 特に喉 頭・気管・食道のいずれかに浸潤を認めた症例につ いて詳細に検討した。

\section{対象と方法}

2008 年〜 2016 年の 9 年間に当科で手術を施行し た甲状腺癌症例 219 症例のうち, 喉頭, 気管, 食道 のいずれかに進展していた症例は 50 症例であった。 そのうち, 26 症例は表層浸潤 (Ex1) と判断され, 軟骨の表層切除や食道筋層切除までの切除が行われ た。これらの症例のうち, 再発を認めた症例は局所 再発が 1 例, 遠隔転移再発が 1 例と比較的予後は良 いものであったため, 喉頭, 気管, 食道いずれかの 合併切除を要した残りの 24 症例（Ex2）のうち, 再発症例, 未分化癌症例, CASTLE 症例を除いた 13 症例の検討を行った。組織型や肉眼的腺外浸潤 は第 6 版甲状腺癌取り扱い規約に基づき分類した。 規約に従い, 周囲臓器に浸潤を認めたものの鋭的剥 離が可能なものを $\mathrm{Ex} 1$ ，それ以上の浸潤を認めたも のを Ex2 と記載した。生存率は Kaplan-Meier 法を 用いて算出した。

当科に扔ける気管浸潤症例と咽頭・食道浸潤症例 の治療方針を示すが (表 1), 切除範囲の決定には 積極的に術中迅速病理診断を用いている。気管浸潤
症例に関しては，表層浸潤に関しては表層切除を行 い, 気管粘膜への腫瘍浸潤や切除断端軟骨の術中迅 速病理診断の陽性例に対しては, 気管合併切除を 行っている。気管欠損への対応として, $1 / 3$ 周以下 の気管欠損に対しては気管皮膚瘦を作成し，1/3 $2 / 3$ 周程度の気管欠損の場合は骨付き皮弁を作成 し，各々二期的に閉鎖を行っている。 $2 / 3$ 周以上の 気管欠損の場合は環状切除を施行している。咽頭・ 食道浸潤に関しては, 筋層までの浸潤の場合は筋層 切除にとどめ, 筋層を越えて粘膜面まで浸潤してい る症例に対しては, 咽頭や食道粘膜の合併切除を 行っている。咽頭・食道欠損が生じても可能ならば 一期的に縫縮し, 広範囲の咽頭欠損に対しては程度 に応じて遊離皮弁や遊離空腸により再建を行ってい る。また, 当科の喉頭全摘術の適応としては, 喉頭 内腔浸潤, 半周以上の輪状軟骨切除症例, 半分以上 の甲状軟骨切除症例としている。

なお, 本研究の臨床的検討に関しては, 当院倫理 委員会の承認を得ている。

\section{結果}

全甲状腺癌症例 219 例の内訳は, 男性 75 例, 女 性 144 例で年齢は 9 88 歳 (平均 57.7 歳) であり, 乳頭癌, 慮胞癌, 低分化癌, 未分化癌, CASTLE がそれぞれ 191 例， 10 例， 14 例， 2 例， 2 例であっ た。さらに, 咽頭, 食道掞よび気管のいずれかに進 展していた肉眼的腺外浸潤の分類にて Ex2にあた る 13 症例 (再発症例, 未分化癌症例, CASTLE 症 例は除く。）の内訳は, 男性 3 例, 女性 10 例で年齢 は $38 \sim 76$ 歳 (平均 62.3 歳) であり, 乳頭癌, 濾 胞癌, 低分化癌がそれぞれ 10 例, 2 例, 1 例であっ た（表 2)。

表 1 気管浸潤, 咽頭 - 食道浸潤に対する治療方針

\begin{tabular}{|c|c|}
\hline \multicolumn{2}{|l|}{ 気管浸潤 } \\
\hline $\begin{array}{l}\text { 表層気管浸潤 } \\
\text { 気管粘膜への浸潤 } \\
\langle 3 \text { 気管輪以上の気管欠損が生じた場合 }\rangle \\
\cdot 1 / 3 \text { 周以下の気管欠損 } \\
\cdot 1 / 3 \sim 2 / 3 \text { 周程度の気管欠損 } \\
\cdot 2 / 3 \text { 周以上の気管欠損 }\end{array}$ & $\begin{array}{l}\text { : 表層切除。 } \\
\text { : 気管軟骨合併切除。 } \\
\text { : 気管皮膚瘦孔を作成し，二期的に瘻孔閉鎖。 } \\
\text { : 骨付き皮弁を作成し，二期的に瘦孔閉鎖。 } \\
\text { : 環状切除。 }\end{array}$ \\
\hline \multicolumn{2}{|l|}{ 咽頭・食道浸潤 } \\
\hline $\begin{array}{l}\text { O食道筋層までの浸潤 } \\
\text { 食道筋層を越える浸潤 } \\
\text { 〈食道・咽頭欠損が生じた場合〉 } \\
\text { •わずかな食道, 咽頭粘膜欠損 } \\
\text { • 中等度の食道, 咽頭粘膜欠損 } \\
\text { ・咽頭から喉頭までの広範囲の欠損 }\end{array}$ & $\begin{array}{l}: \text { 筋層切除。 } \\
: \text { 食道粘膜合併切除。 } \\
: \text { 縫縮。 } \\
: \text { 遊離皮弁によるパッチ。 } \\
: \text { 遊離皮弁や遊離空腸による再建。 }\end{array}$ \\
\hline
\end{tabular}


表 2 症例の内訳（全症例および $\mathrm{Ex} 2$ 症例 $)$

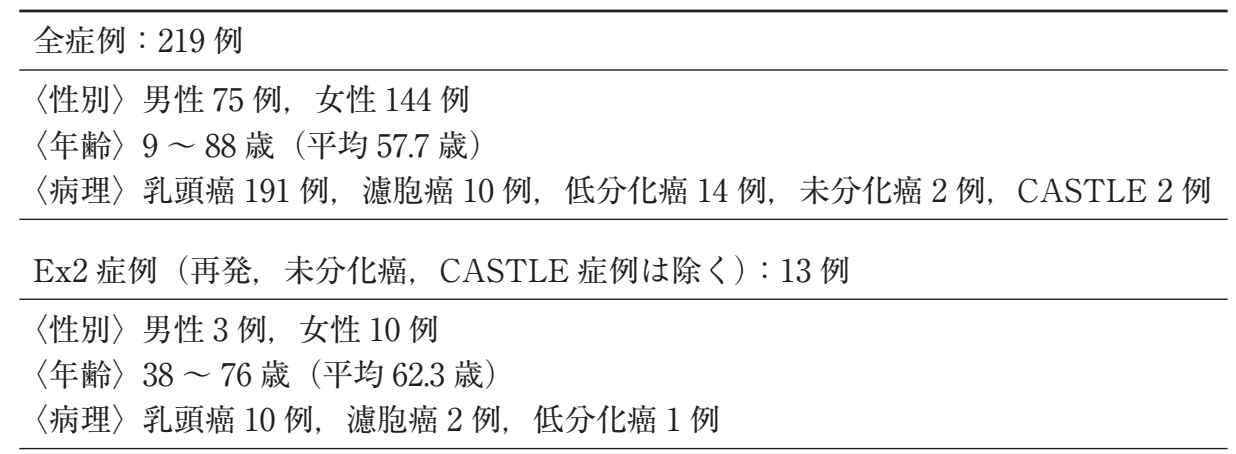

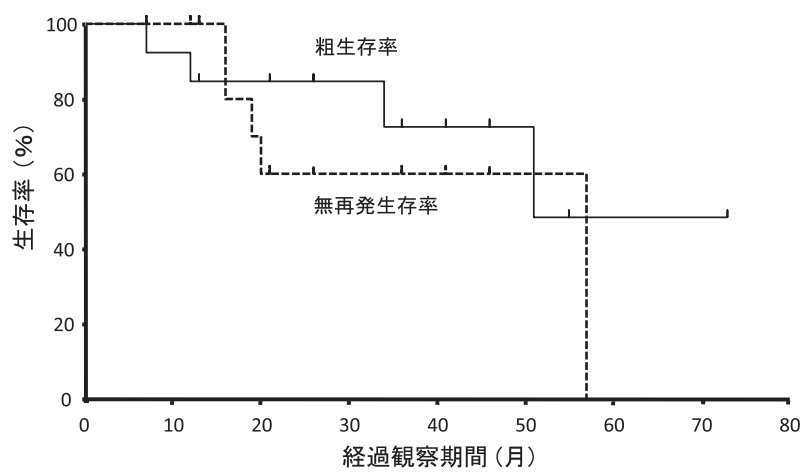

図 1 周囲浸潤 13 症例の粗生存率と無増悪生存率

Ex2 13 症例の術後経過観察期間は $7 〜 73$ か月 (平均 33.9 か月) であり, 3 年粗生存率は $72.5 \%, 3$ 年無再発生存率は $60.0 \%$ であった（図 1)。死亡例 は肺転移死が 1 例, 他因死（感染性心内膜炎 1 例, 肺炎 1 例，心血管系疾患 1 例）が 3 例となってお り，再発形式別では，遠隔転移が 3 例（肺転移 2 例, 脳転移 1 例), 健側リンパ節再発が 1 例, 局所 再発が 1 例であった。浸潤部位は気管のみの浸潤が 4 例，気管と輪状軟骨浸潤が 5 例，気管と食道浸潤 が 1 例，気管，輪状軟骨と甲状軟骨浸潤が 3 例で あった（表 3)。気管のみの浸潤症例 4 例は全例で 気管皮膚瘦を作成しており，そのうちの 2 例は局所 皮弁を用い，1例は DP 皮弁を用い，1例は橈骨付 き前腕皮弁を用いていた。気管と輪状軟骨浸潤症例 5 例のうち，2 例は局所皮弁を用いて気管皮虐瘦を 作成しており，3例は喉頭全摘術を行っていた。気 管と喉頭浸潤症例 2 例のうち, 喉頭部分切除を行 い，前腕皮弁再建を行った症例が 1 例，喉頭全摘術 を行った症例が 1 例であった。気管と食道浸潤症例 1 例は，食道の欠損が大きかったため, 前腕皮弁を 筒状にして再建した。気管, 輪状軟骨抢よび甲状軟 骨浸潤の 3 例に対しては, 喉頭全摘術を行った症例 が 1 例，喉頭部分切除を行った症例が 2 例であった。 喉頭部分切除を行った症例のうち，1例は前腕皮弁， もう 1 例は橈骨付き前腕皮弁により再建した。
13 例のうち, 喉頭全摘術を要した症例は 4 例で あり，一期的に喉頭全摘術を行った症例が 2 例，二 期的に喉頭全摘術を行った症例が 2 例であった。一 期的に喉頭全摘術を行った症例は，気管と輪状軟骨 浸潤症例の 1 例であり（図 $2 \mathrm{a}, \mathrm{b})$ ，もう 1 例は, 気管，輪状軟骨および喉頭浸潤症例であった (図 2c, d)。二期的に喉頭全摘術を行った症例は, 気管と輪状軟骨浸潤症例の 2 例であり，2 例とも初 回に気管切除と輪状軟骨の広範囲の表層切除を行っ ているが，感染に伴う血流不全により創部壊死が生 じたために，初回手術の 2 週間後に喉頭全摘術を 行っている。以上のように Ex2 13 症例に対しては, 積極的に浸潤藏器の合併切除が行われたが，残念な がら 1 例にのみ局所再発を認めた。この局所再発を 来した 1 例を示す。

\section{【症例】}

年齢：60 代，男性，濾胞癌。

甲状腺右葉滤胞癌 (cT4aN1bM1 原発巣は気管, 輪状軟骨粘膜に浸潤あり。肺，椎骨，腎，肋骨，上 腕骨転移あり（図 3)。）に対し，200W 年に甲状腺 全摘術（輪状軟骨および気管円密切除），両頸部郭 清術を行い，前胸壁皮弁による気管皮膚瘦作成術を 施行した。その後, 放射線ヨード内用治療 (RAI) を 6 回施行し，頸椎と肋骨には鎮痛目的の外照射治 療を施行した。200W +5 年に気管再建部に再発を 認め, 輪状軟骨粘膜に広く浸潤していたため, 喉頭 全摘術および気管合併切除を施行した。その後, RAI 2 回施行するも遠隔転移の増大を認め, 骨 転移部位の疼痛が強くなってきたこともあり, $200 \mathrm{~W}+7$ 年にレンバチニブの導入となった。その 後, 遠隔転移部の縮小を認め, 原発巣はコントロー ルされており，現在も治療継続中である。

\section{考察}

甲状腺は咽頭，食道，喉頭，気管，総頸動脈，内 頸静脈および反回神経など重要臓器に囲まれている ため, 甲状腺癌が被膜外進展した場合には周囲臓器 
表 $3 \mathrm{Ex} 2$ 症例の術式と再建材料

\begin{tabular}{|c|c|c|}
\hline 浸潤部位 & 術式（合併切除） & 再建材料 \\
\hline 気管（4） & $\begin{array}{l}\text { 気管円空切除 } \\
\text { +気管皮膚癭作成 }\end{array}$ & $\begin{array}{l}\text { ·局所皮弁 (2) } \\
\cdot \text { DP 皮弁 (1) } \\
\text { ·橈骨付き前腕皮弁 (1) }\end{array}$ \\
\hline 気管＼cjkstart輪状軟骨（5） & $\begin{array}{l}\text { 気管, 輪状軟骨円空切除 } \\
\text { + 気管皮膚瘻作成 }(2)\end{array}$ & ·局所皮弁（2） \\
\hline & 喉頭全摘術（3） & \\
\hline 気管 食道 (1) & $\begin{array}{l}\text { 食道粘膜合併切除 } \\
+ \text { 気管円空切除 }\end{array}$ & ·前腕皮弁 \\
\hline 気管 輪状軟骨 喉頭（3） & $\begin{array}{l}\text { 喉頭部分切除術（2） } \\
\text { 喉頭全摘術（1） }\end{array}$ & $\begin{array}{l}\cdot \text { 前腕皮弁 } \\
\text { ·橈骨付き前腕皮弁 }\end{array}$ \\
\hline
\end{tabular}

（ ）は症例数を示す。
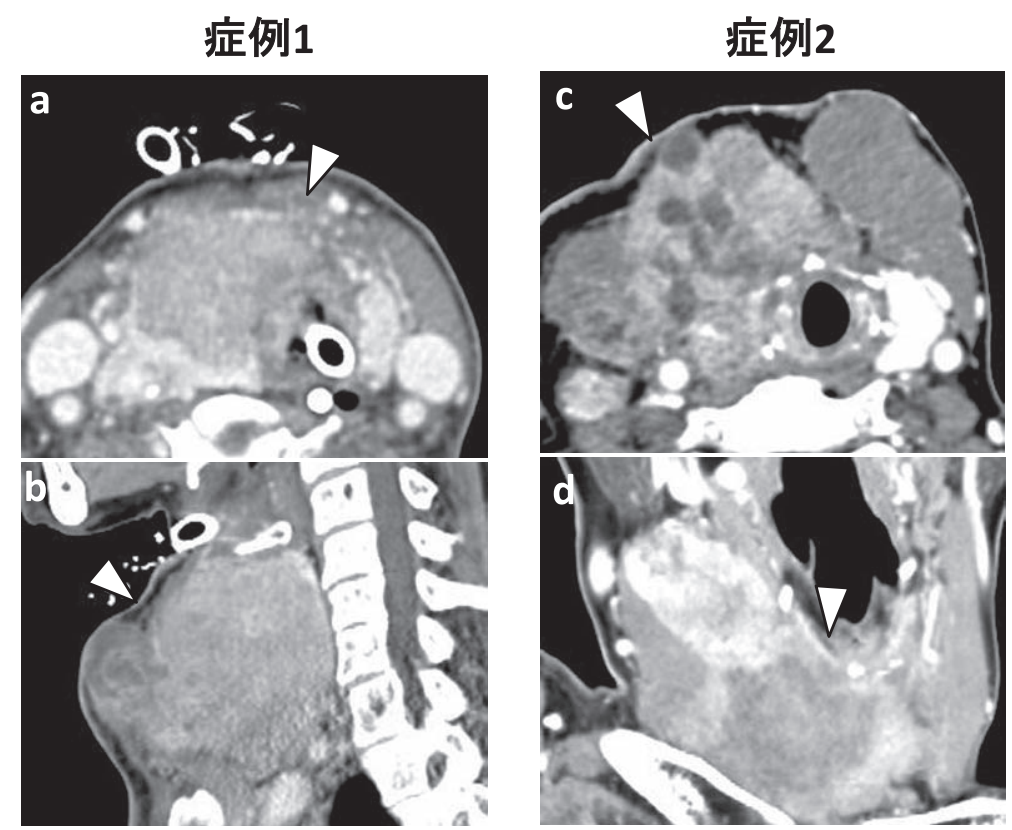

図 2 喉頭全摘症例の造影 CT

$\mathrm{a}$ : 症例 1 (軸位断), b : 症例 1 (糸状断), $\mathrm{c}$ ：症例 2 (軸位断), $\mathrm{d}$ : 症例 2 (冠状断), $\Delta$ : 腫瘍

に直接浸潤し易い。当科の甲状腺癌症例において は, 術中所見にて周囲臓器への浸潤が確認された症 例は全 219 症例中 50 例であった。そのうち，わず かな浸潤 (Ex1) と判断され, 気管軟骨の表層切除 や食道筋層切除までの切除が行われた症例が 26 例 存在したが, 再発を認めたのは 2 例のみ（局所再発 1 例，遠隔転移再発 1 例）であり，諸家の報告同様 に気管もしくは食道浅層までの切除例の予後は良い 結果であった。

一方, 喉頭, 気管, 食道いずれかの浅層を越えて 切除を要した症例 (Ex2) が 24 例存在した。甲状 腺癌, 特に分化癌の 10 年生存率は $90 \%$ 前後と良好
であることが知られている。その一方で, 周囲臓器 への深部浸潤症例の局所制御や予後は悪いことが報 告されているが, 術式の決定に際する一定のエビデ ンスはそしいのが現状である。甲状腺診療ガイドラ イン ${ }^{2)} に は ，$ 気管浸潤例においては，気管環状切除 と（表層切除を含めた）気管部分切除に対する成績 比較の報告がないことが記されており，進行例およ び高リスク群では根治的な切除を行うことを推奨し ている。しかし, 腫瘍切除に際し, 肉眼的な腫瘍残 存がなければ顕微鏡的な残存は許容されるとする報 告がある ${ }^{3-7)}$ 一方で, 気管浸潤例に対して表層切除 例は気管合併切除例よりも多くの再発を認めたとす 


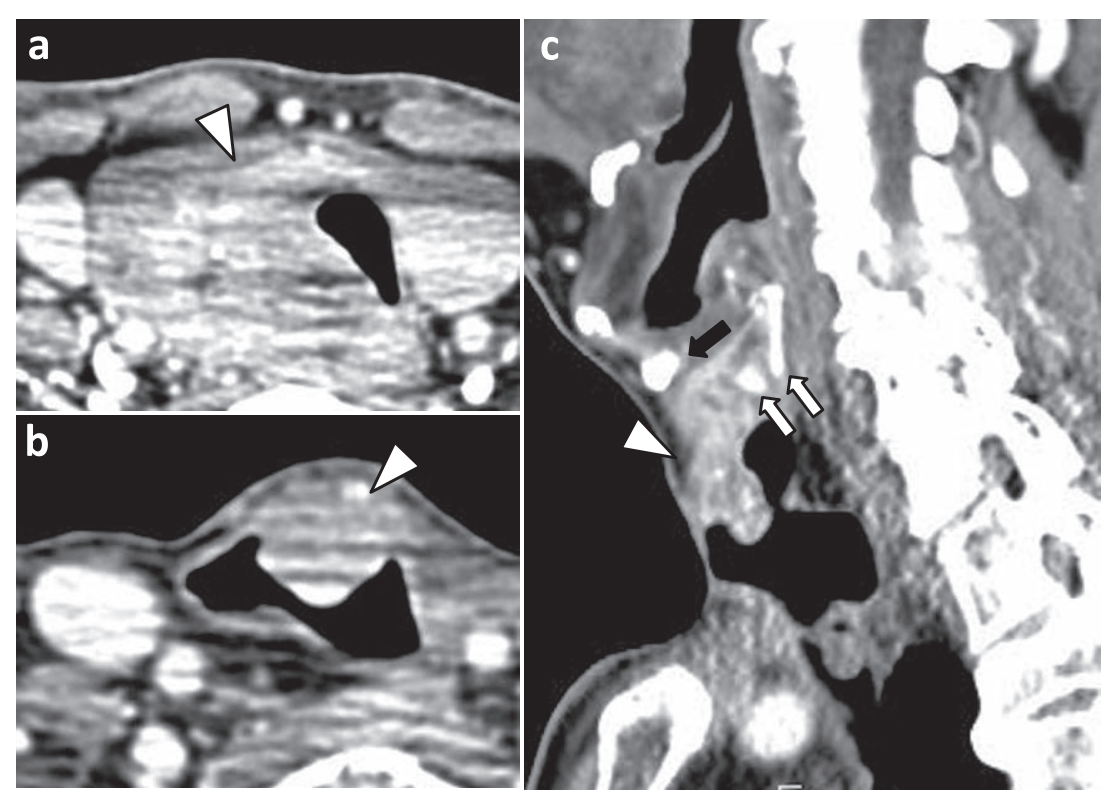

図 3 症例 1 造影 CT

$\mathrm{a}$ : 初回手術前, b : 局所再発時 (軸位断), $\mathrm{c}$ : 局所再発時 (矢状断),

$\Delta$ : 腫瘍, $\Rightarrow$ : 甲状軟骨, $\Rightarrow$ : 輪状軟骨

る報告もある ${ }^{8,9)}$ 。これらを踏まえ, 当科の $\mathrm{Ex} 2$ 症 例に対する治療は, 迅速病理診断を重要視した根治 切除を基本方針としている。

当科の 24 例中, 再発症例, 未分化癌症例, CAS TLE 症例は除いた Ex2 13 症例において局所再発し た症例は 1 例 $(7.7 \%$ ）のみだったが，遠隔転移再 発が 3 例 $(23.1 \%)$ と高率であった。 3 年粗生存率 も $72.5 \%$ と決して良いとは言えない結果であった が，その内訳は他因死が 3 例であり, 疾患特異的な 死因は肺転移死 1 例のみであった。

山田らは周囲臟器浸潤を認めた甲状腺乳頭癌 72 症例を詳細に検討している ${ }^{1)}$ 。年齢, 性別, 外側区 域リンパ節転移, 初診時遠隔転移, 反回神経浸潤, 喉頭浸潤, 気管浸潤, 食道浸潤, 複数臓器への浸 潤, 甲状腺全摘などを予後因子とした単変量解析を 行っており, 疾患特異的生存率は, 初診時遠隔転 移, 気管浸潤, 複数臓器浸潤で有意に低い結果で あった。局所再発は $9.7 \%$ に認めており，有意な局 所制御の予後因子としては, 喉頭浸潤, 食道浸潤, 複数臓器への浸潤を挙げている。また, 遠隔転移出 現率は, 喉頭浸潤, 気管浸潤, 食道浸潤および複数 臓器への浸潤で有意差を認めている。

さらに浸潤臓器別（反回神経，喉頭，気管，食 道) に多変量解析を行い, 疾患特異的生存率, 遠隔 転移出現率に関して検討している。前者は気管浸 潤，後者は喉頭浸潤と気管浸潤で有意差を認めてお り，気管浸潤を最も危険度の高い予後因子としてい る。当科の症例においても, $\mathrm{Ex} 2$ 症例全例が気管浸 潤を認めていた。未だ観察期間が短いこともあり，
今後も厳密な経過観察が必要であると考える。

今回の検討では, Ex2 13 症例のうち, 2 例で一 期的に喉頭全摘術が行われていた。CT（図 3）に 示したとおり, 症例 1 は広範囲の輪状軟骨浸潤を認 めており, 症例 2 は甲状軟骨の半分以上, 更に輪状 軟骨の半周以上の浸潤を認めていた。当科の喉頭全 摘術の適応としては, 喉頭内腔浸潤, 半周以上の輪 状軟骨切除を要する症例, 半分以上の甲状軟骨切除 を要する症例としている。喉頭全摘術は, 失声や永 久気管孔という QOL を大きく損なう術式である反 面, 喉頭部分切除術に付随する誤茧のリスクを回避 できるため, 上記の適応基準や迅速病理診断の結果 に加えて, 年齢や併存疾患, 術前の嚥下機能, 家族 背景, 予後などを十分に考慮した上で切除範囲を決 定する必要がある。

Ex2 13 症例のうち 1 例のみ局所再発を認め, 再 手術を行っている。その再発症例は, 初回手術時に 気管内腔浸潤を認めた症例であった。気管の切除断 端に肉眼的腫瘍残存を認めず, 更に気管内腔粘膜切 除断端の術中迅速病理診断にて癌の浸潤がないこと を確認しているが, 術後の永久病理診断にて切除断 端近傍に癌が浸潤していていることが判明し, 完全 切除になっていなかった可能性が示唆された。安全 域が極めて少なかったことが再発の原因と推測され る。Suらの報告では, 気管切除を要する気管浸潤 症例に扮いて断端陰性症例と顕微鏡的断端陽性症例 の間に局所制御率の違いはないとしているが10), 99\%の症例に対して術後の外照射を行っている。ま た, RAI 後の外照射は顕微鏡的残存腫瘍に対して 
有効であるという報告もあるものの，術後外照射の 意義は現時点では不明であり，本邦では一般的な治 療にはなっていない。気管内腔粘膜への浸潤を認め るような浸潤傾向の強い腫瘍の場合には，十分な安 全域を確保した切除が必要であると考える。

甲状腺癌局所進行例の治療には，手術や RAI 以 外に，外照射や分子標的薬も治療選択肢として挙げ られる。当科では, 初回治療例に対し, 外照射を使 用した経験はないが，術後の局所再発例に対して外 照射を行っている報告11) も認められ，状況によっ ては治療選択肢のひとつになるかと考える。また, 2014 年から 2015 年にかけてソラフェニブ, レンバ チニブおよびバンデタニブといったチロシンキナー ゼ阻害薬が，甲状腺癌に対し保険収載された。根治 切除不能な分化型甲状腺癌に対しは, ソラフェニブ とレンバチニブが適応となっているが，両者とも甲 状腺全摘術と RAI が行われていることが前提と なっている。甲状腺癌局所進行例に対しては, 根治 切除後にRAI の導入を積極的に考慮した上で，こ れら分子標的薬の適応を常に念頭に置いた厳重な経 過観察が肝要と考える。

\section{まとめ}

当科にて手術治療を行った甲状腺癌 219 症例のう ち，未分化癌，CASTLE 症例を除き，喉頭，気管， 食道に浸潤し拡大切除を行った $\mathrm{Ex} 2$ 症例 13 例を検 討した。周囲臓器の合併切除においては慎重な判断 が必要になるが, 年齢や併存疾患, 術前の嚥下機 能，家族背景，予後なども判断材料とした上で，広 範囲の浸潤を認めた場合は積極的な拡大切除を考慮 しなければならないと考える。

著者は申告すべき利益相反を有さない。

\section{文献}

1）山田光一郎, 田中信三, 平塚康之, 他：甲状腺乳頭 癌周囲臓器浸潤例における予後の検討。日耳鼻, $118: 115-122,2015$.

2) 日本内分泌外科学会・日本甲状腺外科学会編：甲状 腺腫瘍診療ガイドライン 2010，125-126, 金原出版, 2010.

3) McCarty TM, Kuhn JA, Williams WL, Jr, et al: Surgical management of thyroid cancer invading the airway. Ann Surg Oncol $4:$ 403-408, 1997.

4) Czaja JM, McCaffrey TV: The surgical management of laryngotracheal invasion by well-differentiated papillary thyroid carcinoma. Arch Otolaryngol Head Neck Surg 123 : 484-490, 1997.

5) Wada N, Nakayama H, Masudo Y, et al: Clinical outcome of different modes of resection in papillary thyroid carcinomas with laryngotracheal invasion. Langenbecks Arch Surg 391 : 545-549, 2006.

6) Tsukahara K, Sugitani I, Kawabata K: Surgical management of tracheal shaving for papillary thyroid carcinoma with tracheal invasion. Acta Otolaryngol 129 : 1498-1502, 2009.

7) Ito Y, Fukushima M, Yabuta T, et al: Local prognosis of patients with papillary thyroid carcinoma who were intra-operatively diagnosed as having minimal invasion of the trachea: a 17-year experience in a single institute. Asian J Surg 32 : 102-108, 2009.

8) Park CS, Suh KW, Min JS: Cartilage-shaving procedure for the control of tracheal cartilage invasion by thyroid carcinoma. Head Neck 15 : 289$291,1993$.

9) Tsai YF, Tseng YL, Wu MH, et al: Aggressive resection of the airway invaded by thyroid carcinoma. Br J Surg 92 : 1382-1387, 2005.

10) Su SY, Milas ZL, Bhatt N, et al: Well-differentiated thyroid cancer with aerodigestive tract invasion: Long-term control and functional outcomes. Head Neck $38: 72-78,2016$.

11）吉田大作, 玉木義雄, 清原浩樹, 他: 甲状腺癌術後 再発病変に対する外照射の検討一多施設共同研究—. The Kitakanto Medical Journal, 65：165, 2015. 